\title{
Bacillus cereus cytotoxins Hbl, Nhe and CytK are secreted via the Sec translocation pathway
}

Annette Fagerlund ${ }^{1,2}$, Toril Lindbäck ${ }^{1 *}$, Per Einar Granum ${ }^{1}$

\begin{abstract}
Background: Bacillus cereus and the closely related Bacillus thuringiensis are Gram positive opportunistic pathogens that may cause food poisoning, and the three secreted pore-forming cytotoxins Hbl, Nhe and CytK have been implicated as the causative agents of diarrhoeal disease. It has been proposed that the Hbl toxin is secreted using the flagellar export apparatus (FEA) despite the presence of Sec-type signal peptides. As protein secretion is of key importance in virulence of a microorganism, the mechanisms by which these toxins are secreted were further investigated.

Results: Sec-type signal peptides were identified in all toxin components, and secretion of Hbl component B was shown to be dependent on an intact Sec-type signal peptide sequence. Further indication that secretion of $\mathrm{Hbl}$, Nhe and CytK is dependent on the Sec translocation pathway, the main pathway on which bacterial secretion relies, was suggested by the observed intracellular accumulation and reduced secretion of the toxins in cultures supplemented with the SecA inhibitor sodium azide. Although a FEA deficient strain (a flhA mutant) showed reduced toxin expression and reduced cytotoxicity, it readily secreted overexpressed $\mathrm{Hbl} \mathrm{B}$, showing that the FEA is not required for $\mathrm{Hbl}$ secretion. Thus, the concurrent lack of flagella and reduced toxin secretion in the FEA deficient strain may point towards the presence of a regulatory link between motility and virulence genes, rather than FEA-dependent toxin secretion.
\end{abstract}

Conclusions: The Hbl, Nhe and CytK toxins appear to be secreted using the Sec pathway, and the reduced Hbl expression of a FEA deficient strain was shown not to be due to a secretion defect.

\section{Background}

Bacillus cereus and the closely related Bacillus thuringiensis are Gram positive bacteria belonging to the $B$. cereus group, recognized as causative agents of gastrointestinal disease. Three pore-forming toxins appear to be responsible for the diarrhoeal type of food poisoning: Hemolysin $\mathrm{BL}(\mathrm{Hbl})$, Non-haemolytic enterotoxin (Nhe), and Cytotoxin K (CytK) [1]. Since B. thuringiensis is only differentiated from $B$. cereus by the presence of plasmids encoding insecticidal crystal toxins [2], B. cereus and B. thuringiensis show a similar prevalence and expression of genes encoding these cytotoxins [3,4]. Hbl and Nhe each consist of three different protein components, named $L_{2}, L_{1}$, and $B$, and NheA, NheB and

\footnotetext{
* Correspondence: toril.lindback@nvh.no

'Norwegian School of Veterinary Science, Department of Food Safety and Infection Biology, PO Box 8146 Dep., N-0033 Oslo, Norway

Full list of author information is available at the end of the article
}

NheC, respectively, while CytK is a single-component toxin [1].

The expression of the B. cereus cytotoxins is positively regulated by a quorum sensing system composed of the transcriptional activator PlcR and its activating peptide PapR [5]. Expression of $\mathrm{Hbl}$ and Nhe is also regulated by the redox-sensitive two-component regulatory system ResDE and the redox regulator Fnr [6,7], and to a lesser extent the catabolite control protein CcpA [8], demonstrating a link between virulence and the metabolic state of the cell. In many pathogenic bacteria, the expression of motility genes and virulence factors are co-ordinately regulated [9], and a regulatory link between motility and virulence appears to exist also in B. cereus and B. thuringiensis, which are motile by peritrichous flagella. For example, motility was reduced in a plcR mutant [10], transcription of the genes encoding $\mathrm{Hbl}$ and phosphatidylinositol-specific phospholipase $C$ was reduced in the non-flagellated flhA mutant [11], and Hbl production 
increased during swarming migration [12]. However, the molecular mechanisms that putatively couple the expression of virulence factors to motility have not been elucidated.

Protein secretion is of key importance in virulence of a microorganism, as bacterial protein toxins must cross the bacterial membrane(s) in order to gain access to their site of action at the target host cell. It has been suggested that the $\mathrm{Hbl}$ proteins are secreted using the flagellar export apparatus (FEA), as non-flagellated strains were deficient in $\mathrm{Hbl}$ secretion $[12,13]$, but the pathways used to translocate Nhe and CytK from the bacterial cell have not been investigated. In Gram positive bacteria, in which secreted proteins only have to cross a single lipid bilayer, six protein secretion systems are currently recognized [14-16]: The general secretory (Sec) pathway, the twin arginine targeting (Tat) pathway, the fimbrillin-protein exporter (FPE), the FEA, the holins, and the WXG100 secretion system (Wss). The Sec pathway is considered the general housekeeping protein translocation system and is essential in all bacteria for which it has been studied. To gain further insight into the pathogenesis of $B$. cereus and the relationship between toxin production and motility in this bacterium, the current study aims to elucidate which secretion pathway is used to export the B. cereus $\mathrm{Hbl}$, Nhe and CytK cytotoxin components.

\section{Results and discussion}

\section{The $B$. cereus cytotoxins contain Sec-type signal peptide} sequences

Sec-type signal peptides target proteins for secretion via the Sec translocation pathway, and are characterized by a positively charged amino-terminus, a stretch of hydrophobic residues and a cleavage site for a signal peptidase $[17,18]$. The protein components of the B. cereus toxins $\mathrm{Hbl}$, Nhe, and CytK all contain Sec-type signal peptides, as determined by analysis using the SignalP prediction method [19] (Figure 1A).

Signal peptides are cleaved upon secretion. In the original reports describing $\mathrm{Hbl}$, Nhe, and CytK, aminoterminal sequencing using Edman degradation was performed on proteins purified from culture supernatants. These sequences correspond to the predicted aminotermini of the mature proteins in the case of all three $\mathrm{Hbl}$ proteins, NheB and CytK [20-22]. The aminoterminal sequence of purified NheA started 11 amino acids downstream of the predicted signal peptidase cleavage site [21], but since a slightly larger form of NheA has also been isolated [23], this protein probably represents a further processed form. NheC has not been purified from culture supernatant and thus has not been subjected to amino-terminal sequencing. Secretion of CytK into the periplasmic space in the Gram negative
Escherichia coli [24] further indicates that CytK is produced with a functional signal peptide.

To examine whether the signal peptide sequence was required for secretion of one of the $\mathrm{Hbl}$ components, the gene encoding $\mathrm{Hbl} \mathrm{B}$ was expressed from the $x y l A$ promoter on a low-copy plasmid. Three of the uncharged amino acid residues present in the hydrophobic core of the $\mathrm{Hbl} \mathrm{B}$ signal peptide were replaced with negatively charged, hydrophilic amino acid residues: V12E, L15E and I18 D (Figure 1B). Hbl B with intact and mutant signal peptides were expressed in the Hbl-negative strain B. cereus NVH 0075/95, and the levels of expressed protein in the supernatant and cell lysate was examined using Western blot analysis (Figure 1C). The results show that $\mathrm{Hbl} B$ with intact signal peptide was secreted into the culture supernatant, while $\mathrm{Hbl} \mathrm{B}$ containing the mutant signal peptide was exclusively associated with the cell pellet, confirming that secretion of $\mathrm{Hbl} \mathrm{B}$ was dependent on an intact signal peptide sequence.

\section{$\mathrm{Hbl} \mathrm{B}$ secretion is not dependent on the FEA}

The components of the flagellar export apparatus (FEA) are homologous to the proteins of type III secretion

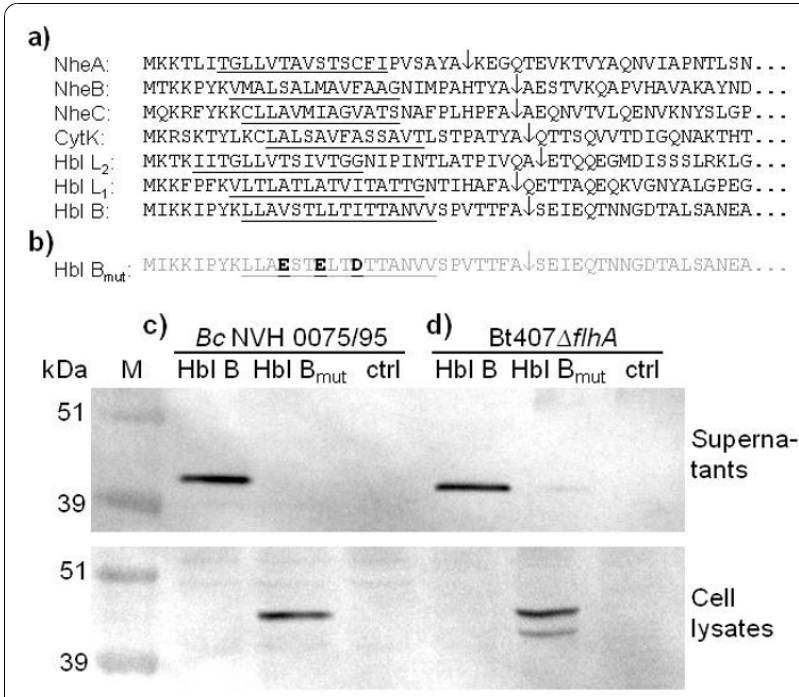

Figure 1 The $B$. cereus toxins contain Sec-type signal peptides (A) Sec-type signal peptide sequences of the Hbl, Nhe and CytK cytotoxin proteins from B. cereus ATCC 14579 predicted using SignalP. The predicted cleavage sites are marked with arrows and the hydrophobic regions are underlined. (B) Site-directed mutations introduced into the hydrophobic core of the signal peptide of $\mathrm{Hbl}$ $\mathrm{B}$ in this study. Western immunoblot analysis of $\mathrm{Hbl} \mathrm{B}$ in culture supernatants and cell lysates of $(\mathbf{C}) B$. cereus $(B C)$ NVH0075/95 and (D) the non-flagellated B. thuringiensis 407 flhA mutant (Bt407 $\mathrm{flh} A$ ) transformed with pHT304-pXyl expressing native $\mathrm{Hbl} \mathrm{B}$ and $\mathrm{Hbl} \mathrm{B}$ with a mutated signal peptide sequence $\left(\mathrm{Hbl} \mathrm{B}_{\text {mut }}\right)$. Negative controls are strains harbouring pHT304-pXyl empty vector (ctrl). Expression was induced by $20 \mathrm{mM}$ xylose. Lane M: molecular weight marker. 
systems present in many Gram negative bacteria [25,26], and exports flagellar proteins into the central channel found within the flagellar basal body complex. It has been claimed that the FEA is required for Hbl secretion, as three non-flagellated $B$. cereus/B. thuringiensis strains were shown to fail to secrete $\mathrm{Hbl}[12,13]$. However, it was not determined whether the reduction in the level of secreted $\mathrm{Hbl}$ was due to reduced transcription, translation, or a secretion defect. To further investigate the secretion pathway of $\mathrm{Hbl}, \mathrm{Hbl} \mathrm{B}$ with intact and mutant signal peptides were expressed as described above in one of the previously described $B$. thuringiensis nonflagellated strains, Bt407 mutated in flhA encoding a component of the FEA [13] (Figure 1D). This approach clearly showed that overexpressed $\mathrm{Hbl} \mathrm{B}$ was secreted in the FEA deficient strain, demonstrating that the FEA was not required for secretion of $\mathrm{Hbl} \mathrm{B}$. Overexpressed $\mathrm{Hbl} \mathrm{B}$ with mutant signal peptide was almost exclusively associated with the cell pellet. A second band of lower molecular weight than intact $\mathrm{Hbl} \mathrm{B}$ in the lane containing the cell pellet from the FEA-deficient strain likely represents a degradation product of mutant $\mathrm{Hbl} \mathrm{B}$, while a weak band in the lane containing the supernatant fraction may represent native chromosomally encoded $\mathrm{Hbl} \mathrm{B}$ protein or originate from lysed cells.

\section{Secretion of cytotoxins was inhibited by the SecA inhibitor azide}

The Sec translocation pathway in Gram positive bacteria is composed of the SecYEG membrane channel and of SecA, the ATPase that drives the translocation reaction through the SecYEG channel. Sodium azide markedly inhibits Sec-dependent preprotein membrane translocation in vivo and in vitro [27]. Although azide also inhibits other ATPases [28], it has been shown both in E. coli and in Bacillus subtilis that azide-resistance may be conferred by specifically mutating SecA [29-31], indicating that SecA is the major target for the lethal action of azide in bacteria. Since deletion mutants in essential components of the Sec translocation pathway are nonviable [32], the Sec-dependence of B. cereus $\mathrm{Hbl}$, Nhe, and CytK toxin secretion was investigated by addition of sodium azide to cultures of B. cereus ATCC 14579. For this purpose, it was essential to study the secretion of $d e$ novo synthesised toxins, otherwise the effect of azide would be overshadowed by toxins accumulated in the growth medium. Therefore, cells grown to transition phase $\left(t_{0}\right)$ were washed and resuspended in culture medium with and without added azide. Culture supernatants were harvested 20 minutes after addition of azide, to minimize pleiotropic effects potentially affecting toxin secretion indirectly. Furthermore, activation of PlcR, the transcriptional regulator required for $B$. cereus cytotoxin expression, is dependent on PapR, a 48 amino acid peptide with a Sec-type signal peptide thought to be secreted by the Sec pathway and reimported after extracellular processing [33]. To ensure that potential inhibition of toxin secretion by addition of azide was not an indirect effect due to lack of PapR secretion, a culture containing both azide and synthetic PapR pentapeptide was included. The concentration of azide used $(2 \mathrm{mM})$ was chosen as this was the lowest concentration of azide that inhibited growth of B. cereus ATCC 14579 on agar plates.

The Western blot analysis shown in Figure 2A detecting $\mathrm{Hbl}$, Nhe, and CytK proteins shows that in the presence of azide, secretion of the toxins into the culture medium was reduced, while cell lysates contained increased levels of toxins, indicating intracellular accumulation. Incomplete inhibition of toxin secretion in the presence of azide may be due to residual activity of the SecA ATPase at the azide concentration employed. Multiple band patterns in the cell lysates are likely to represent pre-proteins, mature forms, and/or intracellularly degraded forms of the toxins. Addition of PapR to the azide-containing culture resulted in increased toxin production, as cell lysates contained increased levels of the examined toxin proteins, and is probably the result of enhanced activation of PlcR. Importantly, this increase was only observed in the intracellular fraction, and addition of PapR did not alleviate the reduction in the amount of toxins secreted into the culture medium caused by the addition of azide. The effect of azide on secretion of $\mathrm{Hbl}$ component $\mathrm{L}_{1}$ could not be assessed, as we were unable to detect this component in culture supernatants of the wild-type strain, probably as this

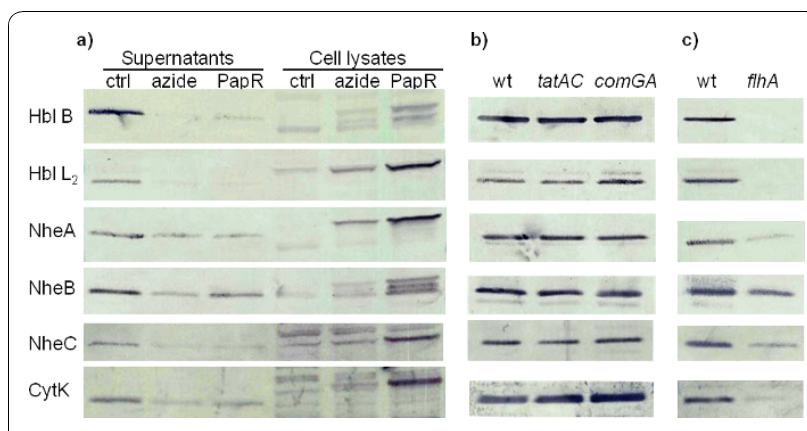

Figure 2 Western immunoblot analysis of the level of toxin components upon treatment with the SecA inhibitor azide and in Tat, Com, and FEA mutants. (A) Western blots showing the level of toxin components in B. cereus ATCC 14579 culture supernatants and cell lysates harvested 20 minutes after cells grown to transition phase were washed and resuspended in fresh culture medium with $2 \mathrm{mM}$ sodium azide (azide) or $2 \mathrm{mM}$ sodium azide and $200 \mu \mathrm{M}$ PapR pentapetide (PapR). The control culture (ctrl) was grown in BHI only. Toxin components in culture supernatants from (B) B. cereus ATCC 14579 wild-type (wt), $\triangle t a t A C$, and $\triangle$ comGA strains (C) B. thuringiensis 407 (wt) and its non-flagellated flhA mutant, harvested one hour into stationary phase. 
Table 1 Percentage inhibition of protein synthesis in Vero cells upon addition of varying volumes of concentrated culture supernatants

\begin{tabular}{|c|c|c|c|c|c|c|c|c|}
\hline \multirow[t]{2}{*}{ Strains and samples } & \multirow[t]{2}{*}{$\begin{array}{c}\text { Supernatant } \\
\text { concentration factor }\end{array}$} & \multicolumn{6}{|c|}{$\begin{array}{c}\text { Amount of added concentrated } \\
\text { supernatant }\end{array}$} & \multirow{2}{*}{$\begin{array}{c}\text { Volume for } \\
50 \% \\
\text { inhibition* }\end{array}$} \\
\hline & & $0.3 \mu \mathrm{l}$ & $1 \mu l$ & $3 \mu l$ & $10 \mu \mathrm{l}$ & $30 \mu \mathrm{l}$ & $100 \mu \mathrm{l}$ & \\
\hline ATCC 14579 without azide & 40-fold & $-4 \%$ & $21 \%$ & $37 \%$ & $89 \%$ & & & $4.0 \mu \mathrm{l}$ \\
\hline ATCC 14579 with azide & 40-fold & & & $-7 \%$ & $9 \%$ & $70 \%$ & $100 \%$ & $20 \mu \mathrm{l}$ \\
\hline ATCC 14579 & ten-fold & $-2 \%$ & $50 \%$ & $97 \%$ & $100 \%$ & & & $1.0 \mu \mathrm{l}$ \\
\hline ATCC $14579 \triangle$ tatAC & ten-fold & $2 \%$ & $45 \%$ & $99 \%$ & $100 \%$ & & & $1.1 \mu \mathrm{l}$ \\
\hline ATCC $14579 \triangle \mathrm{comGA}$ & ten-fold & $-5 \%$ & $49 \%$ & $99 \%$ & $100 \%$ & & & $1.0 \mu \mathrm{l}$ \\
\hline Bt407 [p/cA'Z] & ten-fold & $-2 \%$ & $44 \%$ & $90 \%$ & $100 \%$ & & & $1.2 \mu \mathrm{l}$ \\
\hline Bt407 [plcA'Z] $\triangle f l h A$ & ten-fold & & & $16 \%$ & $72 \%$ & $100 \%$ & $100 \%$ & $6.0 \mu \mathrm{l}$ \\
\hline
\end{tabular}

${ }^{*}$ Amount of supernatant required for $50 \%$ inhibition of protein synthesis (measured by $\mathrm{C}^{14}$-leucine incorporation) in Vero cells [35].

protein was only produced in detectable amounts at a time-point later in the growth phase [34]. The toxicity of culture supernatants was measured using the Vero cell cytotoxicity assay [35], showing that addition of azide to the culture reduced supernatant cytotoxicity fivefold (Table 1). These results, together with the detection of Sec-type signal peptides and the demonstration that the signal peptide of $\mathrm{Hbl} \mathrm{B}$ was essential for secretion, indicate that $\mathrm{Hbl}$, Nhe, and CytK secretion is mediated through the Sec translocation pathway.

\section{Other secretion pathways do not appear to be involved in toxin secretion}

In addition to the Sec pathway and the FEA, four other protein secretion systems are currently recognized in Gram positive bacteria [14]. Analysis of the B. cereus genome sequences showed that $B$. cereus encodes the minimal Tat transport machinery [36] and homologues to the FPE, which is the dedicated pseudopilin export pathway and part of the competence development pathway [14,37]. Analysis of mutants in tatAC, encoding the Tat machinery, and $\operatorname{comGA}$, encoding an essential component of the FPE, showed that these pathways were not required for secretion of $\mathrm{Hbl}$, Nhe, and CytK (Figure 2B; Table 1).

Gram positive bacteria furthermore have two specialized secretion systems: holins secreting murein hydrolases [38] and the WXG100 secretion system secreting WXG100 (ESAT-6) family proteins $[39,40]$. Since the B. cereus $\mathrm{Hbl}$, Nhe, or CytK proteins show no resemblance to murein hydrolases or the WXG100 family of proteins it is unlikely that they are exported using these specialized secretion systems, although it cannot be absolutely excluded from our experiments.

\section{The flhA mutant shows reduced toxin expression and} reduced cytotoxicity

It was established above, using an overexpression system, that secretion of $\mathrm{Hbl} \mathrm{B}$ was not dependent on the
FEA (Figure 1D). Further investigation of the Bt407 FEA deficient $f l h A$ mutant by Western immunoblotting (Figure 2C) and Vero cell cytotoxicity assays (Table 1) clearly showed that the culture supernatant contained reduced amounts of the toxin components compared to the wild-type strain. This reduction could not be alleviated by addition of $200 \mu \mathrm{M}$ synthetic PapR pentapeptide to cultures of the $f l h A$ mutant strains (results not shown). The absence of detectable amounts of $\mathrm{Hbl} \mathrm{L}_{2}$ or $\mathrm{B}$ proteins secreted from the flhA mutant (Figure $2 \mathrm{C})$ confirms the previous lack of detection of $\mathrm{Hbl}$ proteins in culture supernatant from this strain [13]. In contrast, the observed reduced levels of CytK in $\Delta f l h A$ culture supernatant contrasts with the previous lack of detection of reduced CytK (HlyIV) production by the flh $A$ mutant in a blood overlay assay [13]. This discrepancy may however be due to the greater sensitivity of the currently used technique. Importantly, no intracellular accumulation of any of the $\mathrm{Hbl}$, Nhe, or CytK toxin components were detected in cell lysates from the flhA mutant using Western blot analysis (results not shown), in contrast to the intracellular accumulation of toxins observed in the cell lysates in the azide-treated cultures (Figure 2A) and in cell lysates from the strains overexpressing $\mathrm{Hbl} \mathrm{B}$ with mutant signal peptide; $\mathrm{Hbl} \mathrm{B}_{\text {mut }}$ (Figure $1 \mathrm{C}$ and $1 \mathrm{D})$. In the case of $\mathrm{Hbl} \mathrm{B}$ expression in the flhA mutant, our result contrast with that of a previous report [13] in which an intracellular protein interpreted to be a degraded form of $\mathrm{Hbl} \mathrm{B}$ was detected, indicating either that the monoclonal antibody employed in that report cross-reacted with a different protein or that the epitope detected by the monoclonal antibody 2A3 against component B [41] used in the current study was not present. Although the growth rate at $32^{\circ} \mathrm{C}$ was somewhat lower for the $f l h A$ mutant compared with the parent strain, this was not the reason behind the reduced cytotoxicity and toxin expression of the flhA mutant, as both strains reached the same cell number at the time of harvest. 


\section{Potential for coordinated regulation of motility and virulence gene expression}

Given the data presented in the current study, the concurrent lack of flagella and reduced toxin secretion in the $f l h A$ mutant is more consistent with a hypothesis of coordinated regulation of motility and virulence genes, rather than FEA-dependent toxin secretion. This is also supported by the previously observed two-fold reduction in transcription of the genes encoding $\mathrm{Hbl}$ in the $f l h A$ mutant [11].

Coordinated regulation of motility and virulence genes has been demonstrated in several pathogenic bacteria (for reviews see e.g. [9,42-44]). While diarrhoea due to $B$. cereus infection presumably occur through destruction of epithelial cells by enterotoxins produced in the small intestine $[45,46]$, the role of motility, if any, in $B$. cereus infection has not been investigated. Nevertheless, several studies suggest that a connection exists between expression of motility and virulence genes also in $B$. cereus and B. thuringiensis: First, an avirulent and non-flagellated $B$. thuringiensis mutant (Bt1302) showed greatly reduced phospholipase and haemolytic activity [47]. A spontaneous suppressor mutation was able to reverse these phenotypes, and although motility was only partially restored, this indicated that these unidentified mutations affected a regulatory pathway shared between genes encoding flagellin, phospholipases, and haemolysins [47]. Bt1302 is not likely to be a $f l h A$ mutant, since their phenotypes differ, for example in expression of flagellin and growth rate at $37^{\circ} \mathrm{C}$ $[11,13,47]$. Second, PlcR, the transcriptional activator of $B$. cereus extracellular virulence factors, appears to also affect motility, as a plcR mutant showed reduced motility on agar plates and reduced flagellin expression $[10,48]$. Third, Hbl production was shown to increase during swarming migration $[12,49]$, a differentiated state where elongated and hyperflagellate swarm cells collectively move across solid surfaces [50]. Notably, it was shown that $h b l$ genes were upregulated during swarming, concomitant with increased expression of flagellar genes, while the majority of other genes regulated by $\mathrm{PlcR}$, including $p l c R$, nhe, and $c y t K$, were downregulated during swarming [49]. Interestingly, upregulation of the $h b l$ operon concomitantly with downregulation of $p l c R$, nhe and other PlcR-regulated genes was also observed in a deletion mutant of the two-component system yvfTU [51]. Finally, the non-flagellated B. thuringiensis flh $A$ mutant examined in the current study additionally shows: (i) reduced phospholipase $C$ activity towards phosphatidylcholine in a gel diffusion assay [13], (ii) two-fold reduction in transcription of the genes encoding $\mathrm{Hbl}$ and phosphatidylinositol-specific phospholipase C, (iii) a generally lower (twofold) protein concentration in culture supernatants, (iv) reduced sporulation efficiency and ampicillin resistance [11], (v) reduced bacterial adhesion to eukaryotic cells [52], (vi) and reduced growth rate at $32^{\circ} \mathrm{C}$. FlhA from B. subtilis was shown to act as an adaptor that interacted with the flagella building blocks flagellin and filament-capping protein FliD, and coordinated their delivery to the FEA [53].

The fact that the $B$. thuringiensis flhA mutation is pleiotropic supports the hypothesis that regulatory pathways are affected, although further work is required to elucidate the molecular mechanisms linking the flagellar assembly defect and the pleiotropic nature of the flh $A$ mutant. The failure of exogenously added PapR to restore toxin production in the $f l h A$ mutant indicates that the relationship between the flagellar assembly defect and toxin expression may be complex.

In contrast to most bacterial systems where a hierarchical regulatory cascade controls the temporal expression and production of flagella, regulation of flagellar motility genes appear to be nonhierarchal in $B$. cereus group bacteria [13], similar to the situation in Listeria monocytogenes, in which flagellar motility is regulated by the transcriptional repressor MogR $[54,55]$. Genes encoding MogR are only found in Listeria and $B$. cereus group species. Interestingly, when allowing one mismatch to the L. monocytogenes consensus MogR site [56], four putative MogR binding sites are found in the $h b l$ promoter. However, further work is required to determine whether a regulatory link between $h b l$ and motility gene expression in $B$. cereus group bacteria may involve MogR.

\section{Conclusions}

The Hbl, Nhe and CytK toxins appear to be secreted using the Sec pathway, as suggested by reduced secretion and intracellular accumulation of these toxins in cultures supplemented with the SecA inhibitor azide and by the presence of Sec-type signal peptides, which for $\mathrm{Hbl} \mathrm{B}$ was shown to be required for toxin secretion. The previous suggestion of FEA dependent $\mathrm{Hbl}$ secretion $[12,13]$ was not supported by results from the current study, since secretion of $\mathrm{Hbl} B$ was shown to be independent of the FEA. Instead, the reduced toxin production exhibited by the FEA deficient mutant potentially points towards unidentified regulatory links between motility and virulence gene expression in $B$. cereus group bacteria.

\section{Methods}

\section{Bacterial strains}

B. cereus strain ATCC 14579 was used for assessing the effect of azide on toxin secretion, for creation of deletion mutants, and for PCR-amplification of $h b l A$. $B$. cereus NVH 0075/95 [21], lacking genes encoding 
$\mathrm{Hbl}$ [57], was used for overexpression of $\mathrm{Hbl}$ component $B$ with and without intact signal peptide sequence. The acrystalliferous $B$. thuringiensis $407 \mathrm{Cry}^{-}$ [plcA'Z] (Bt407) [58] and its nonmotile flhA null mutant MP02 [13], were kind gifts from Dr Emilia Ghelardi (Universita degli Studi di Pisa, Italy). These strains are indistinguishable from the $B$. cereus species due to loss of the plasmids encoding insecticidal crystal toxins $[2,59]$.

\section{Construction of overexpressing strains and deletion mutants}

The low-copy number E. coli/Bacillus shuttle vector pHT304-pXyl, in which $x y l R$ and the $x y l A$ promoter from Bacillus subtilis was inserted into the pHT304 cloning site [60] allowing xylose-inducible expression of downstream cloned genes, was a kind gift from $\mathrm{Dr}$ Didier Lereclus (INRA, France). The gene encoding $\mathrm{Hbl}$ B, hblA [61], was PCR amplified from B. cereus ATCC 14579 using primers tatggatcctaaattggaggaaaatgaaatg and tagaggtaccatgttttagttcactttacaa and inserted into pHT304-pXyl using the primer-incorporated BamHI and KpnI restriction sites (underlined). The resulting plasmid was subjected to site directed mutagenesis using the QuikChange mutagenesis protocol (Stratagene) in order to express a mutated form of $\mathrm{Hbl} \mathrm{B}$ in which three of the amino acids in the hydrophobic central section of the signal peptide sequence were changed into negatively charged amino acids (Figure $1 \mathrm{~A}$ and $1 \mathrm{~B}$ ). The plasmids were introduced by electroporation into B. cereus NVH 0075/95 and Bt407 $f$ flhA [62].

The tatAC operon and the comGA gene in B. cereus ATCC 14579 were deleted by allelic exchange with a spectinomycin resistance cassette $\left(\mathrm{Sp}^{\mathrm{R}}\right)$ from pDG1726 [63] as described [64].

\section{Growth conditions and sample preparation}

$B$. cereus and $B$. thuringiensis were grown in brain heart infusion (BHI) medium at a temperature of $32^{\circ} \mathrm{C}$, since toxin production generally is maximal at this temperature [65]. For analysis of $\mathrm{Hbl} \mathrm{B}$ overexpressing strains, strains containing plasmid were grown for 3 hours in BHI supplemented with $10 \mu \mathrm{g} \mathrm{ml}^{-1}$ erythromycin, induced with $20 \mathrm{mM}$ xylose and grown for 2 hours before harvesting. For analysis of mutant strains, overnight cultures were supplemented with $250 \mu \mathrm{g} \mathrm{ml}^{-1}$ spectinomycin, and culture supernatants and pellets were harvested 1 hour after the onset of stationary phase $\left(t_{0}\right)$, as the concentration of toxins appears to be maximal at this time [34]. $t_{0}$ was defined as the breakpoint in the slope of the vegetative growth phase curve as determined by measuring the optical density at $600 \mathrm{~nm}$. For analysis of inhibition of SecA by sodium azide, ATCC 14579 was grown to $t_{0}$, washed twice in pre-warmed $\mathrm{BHI}$, and resuspended in the original volume of fresh pre-warmed BHI. The culture was divided into three cultures: one containing $\mathrm{BHI}$ only, one containing $2 \mathrm{mM}$ sodium azide, and one containing 2 mM sodium azide and $200 \mu \mathrm{M}$ synthetic PapR pentapeptide LPFEY (corresponding to the five carboxy-terminal amino acids in PapR from B. cereus ATCC 14579), incubated as before for a further 20 minutes, and harvested by centrifugation. Culture supernatants were collected by centrifugation and concentrated tenfold for examination of $\mathrm{Hbl} \mathrm{B}$ overexpressing strains and the tatAC, comGA, and $f l h A$ mutants, or 40 -fold for azide-treated cultures, by precipitation with $80 \%$ ammonium sulphate. Precipitated proteins were dissolved in and dialysed against TES buffer (20 mM Tris pH 7.5, 0.8\% NaCl, 1 mM EDTA). For Western blot analysis of cultures with and without azide and PapR, supernatant proteins were concentrated 40 -fold by precipitation with four volumes of ice-cold acid acetone:methanol $(1: 1 \mathrm{v} / \mathrm{v})$, stored at $-20^{\circ} \mathrm{C}$ overnight, harvested by centrifugation and resuspended in TES buffer. For preparation of cell lysates, cells were washed once with cold PBS buffer, resuspended in TES buffer to $10 \%$ of the original volume of culture. For $\mathrm{Hbl}$ B overexpressing strains, cells were lysed by mechanical disruption using Lysing Matrix B (MP Biomedicals) in a Mini-BeadBeater-8 (BioSpec) according to manufacturer's specifications. For mutant strains and azidetreated cultures, cells were lysed by incubation at $37^{\circ} \mathrm{C}$ for 60 minutes with $1 \mathrm{mg} \mathrm{ml}^{-1}$ lysozyme, followed by six rounds of freezing and thawing. All samples were used within 2 weeks and all experiments were performed at least twice.

\section{Analysis of samples}

Protein electrophoresis was performed using the NuPAGE Novex Bis-Tris gel systems (Invitrogen), using the SeeBlue Plus2 Pre-Stained Standard (Invitrogen) as the molecular weight marker. Western blot analysis was performed according to standard protocols [66]. Monoclonal antibodies $8 \mathrm{~B} 12$ against $\mathrm{Hbl} \mathrm{L}_{2}, 2 \mathrm{~A} 3$ and $1 \mathrm{~B} 8$ against $\mathrm{Hbl} \mathrm{B}$, and $1 \mathrm{C} 2$ against $\mathrm{NheB}$ and $\mathrm{Hbl} \mathrm{L}_{1}, 1 \mathrm{~A} 8$ against NheA (all diluted 1:15), and rabbit antiserum against NheC diluted 1:2000 [41,67,68] were a kind gift from Dr Erwin Märtlbauer (Ludwig-MaximiliansUniversität, Munich, Germany). For detection of CytK, rabbit antiserum diluted 1:2000 was used [24].

The Vero cell cytotoxicity assay was performed as described [35] and measures the percentage inhibition of $\mathrm{C}^{14}$-leucine incorporation in cells due to the cells being subjected to toxins, calculated relative to a negative control where cells were not subjected to toxin sample. The experiments were performed twice, with two to four parallels in each experiment. 


\section{Acknowledgements}

This work was supported by the Research Council of Norway (164805/110).

\section{Author details}

${ }^{1}$ Norwegian School of Veterinary Science, Department of Food Safety and Infection Biology, PO Box 8146 Dep., N-0033 Oslo, Norway. ${ }^{2}$ Laboratory for Microbial Dynamics (LaMDa) and Department of Pharmaceutical Biosciences, University of Oslo, PO Box 1068 Blindern, N-0316 Oslo, Norway.

\section{Authors' contributions}

AF participated in the study design, constructed plasmids and mutants, performed cytotoxicity assays, and wrote the manuscript. AF and TL performed transformations, sampling and Western blot analysis, and TL participated in writing of the manuscript. PEG conceived of the study, participated in its design, and critically revised the manuscript. All authors read and approved the final manuscript.

Received: 23 September 2010 Accepted: 30 November 2010 Published: 30 November 2010

\section{References}

1. Stenfors Arnesen LP, Fagerlund A, Granum PE: From soil to gut: Bacillus cereus and its food poisoning toxins. FEMS Microbiol Rev 2008, 32:579-606.

2. Helgason E, Økstad OA, Caugant DA, Johansen HA, Fouet A, Mock M, Hegna I, Kolstø AB: Bacillus anthracis, Bacillus cereus, and Bacillus thuringiensis - one species on the basis of genetic evidence. Appl Environ Microbiol 2000, 66:2627-2630.

3. Rivera AMG, Granum PE, Priest FG: Common occurrence of enterotoxin genes and enterotoxicity in Bacillus thuringiensis. FEMS Microbiol Lett 2000, 190:151-155

4. Swiecicka I, Van der Auwera GA, Mahillon J: Hemolytic and nonhemolytic enterotoxin genes are broadly distributed among Bacillus thuringiensis isolated from wild mammals. Microb Ecol 2006, 52:544-551.

5. Gohar M, Faegri K, Perchat S, Ravnum S, Økstad OA, Gominet M, Kolstø AB, Lereclus D: The PlcR virulence regulon of Bacillus cereus. PLoS One 2008, 3:e2793.

6. Esbelin J, Jouanneau Y, Armengaud J, Duport C: ApoFnr binds as a monomer to promoters regulating the expression of enterotoxin genes of Bacillus cereus. J Bacteriol 2008, 190:4242-4251.

7. Esbelin J, Armengaud J, Zigha A, Duport C: ResDE-dependent regulation of enterotoxin gene expression in Bacillus cereus: evidence for multiple modes of binding for ResD and interaction with Fnr. J Bacteriol 2009, 191:4419-4426.

8. van der Voort M, Kuipers OP, Buist G, de Vos WM, Abee T: Assessment of CcpA-mediated catabolite control of gene expression in Bacillus cereus ATCC 14579. BMC Microbiol 2008, 8:62.

9. Ottemann KM, Miller JF: Roles for motility in bacterial-host interactions. Mol Microbiol 1997, 24:1109-1117.

10. Callegan MC, Kane ST, Cochran DC, Gilmore MS, Gominet M, Lereclus D: Relationship of plcR-regulated factors to Bacillus endophthalmitis virulence. Infect Immun 2003, 71:3116-3124.

11. Bouillaut L, Ramarao N, Buisson C, Gilois N, Gohar M, Lereclus D, NielsenLeroux C: FlhA influences Bacillus thuringiensis PlcR-regulated gene transcription, protein production, and virulence. Appl Environ Microbiol 2005, 71:8903-8910.

12. Ghelardi E, Celandroni F, Salvetti S, Ceragioli M, Beecher DJ, Senesi S, Wong AC: Swarming behavior and hemolysin BL secretion in Bacillus cereus. Appl Environ Microbiol 2007, 73:4089-4093.

13. Ghelardi E, Celandroni F, Salvetti S, Beecher DJ, Gominet M, Lereclus D, Wong $A C$, Senesi $S$ : Requirement of flhA for swarming differentiation, flagellin export, and secretion of virulence-associated proteins in Bacillus thuringiensis. J Bacteriol 2002, 184:6424-6433.

14. Desvaux $M$, Hébraud $M$ : The protein secretion systems in Listeria: inside out bacterial virulence. FEMS Microbiol Rev 2006, 30:774-805.

15. Desvaux M, Hébraud M, Talon R, Henderson IR: Secretion and subcellular localizations of bacterial proteins: a semantic awareness issue. Trends Microbiol 2009, 17:139-145.

16. Yuan J, Zweers JC, van Dijl JM, Dalbey RE: Protein transport across and into cell membranes in bacteria and archaea. Cell Mol Life Sci 2010, 67:179-199.
17. Tjalsma H, Bolhuis A, Jongbloed JD, Bron S, van Dijl JM: Signal peptidedependent protein transport in Bacillus subtilis: a genome-based survey of the secretome. Microbiol Mol Biol Rev 2000, 64:515-547.

18. Tjalsma $H$, Antelmann $H$, Jongbloed JD, Braun $P G$, Darmon $E$, Dorenbos $R$, Dubois JY, Westers H, Zanen G, Quax WJ, et al: Proteomics of protein secretion by Bacillus subtilis: separating the "secrets" of the secretome. Microbiol Mol Biol Rev 2004, 68:207-233.

19. Bendtsen JD, Nielsen $H$, von Heijne G, Brunak S: Improved prediction of signal peptides: SignalP 3.0. J Mol Biol 2004, 340:783-795.

20. Beecher DJ, Wong AC: Improved purification and characterization of hemolysin $\mathrm{BL}$, a hemolytic dermonecrotic vascular permeability factor from Bacillus cereus. Infect Immun 1994, 62:980-986.

21. Lund T, Granum PE: Characterisation of a non-haemolytic enterotoxin complex from Bacillus cereus isolated after a foodborne outbreak. FEMS Microbiol Lett 1996, 141:151-156.

22. Lund T, De Buyser ML, Granum PE: A new cytotoxin from Bacillus cereus that may cause necrotic enteritis. Mol Microbiol 2000, 38:254-261.

23. Beecher DJ, Wong AC: Identification and analysis of the antigens detected by two commercial Bacillus cereus diarrheal enterotoxin immunoassay kits. Appl Environ Microbiol 1994, 60:4614-4616.

24. Fagerlund A, Ween O, Lund T, Hardy SP, Granum PE: Genetic and functional analysis of the cytK family of genes in Bacillus cereus. Microbiology 2004, 150:2689-2697.

25. Blocker A, Komoriya K, Aizawa S: Type III secretion systems and bacterial flagella: insights into their function from structural similarities. Proc Natl Acad Sci USA 2003, 100:3027-3030.

26. Desvaux M, Hébraud M, Henderson IR, Pallen MJ: Type III secretion: what's in a name? Trends Microbiol 2006, 14:157-160.

27. Jongbloed JD, Antelmann H, Hecker M, Nijland R, Bron S, Airaksinen U, Pries F, Quax WJ, van Dijl JM, Braun PG: Selective contribution of the twinarginine translocation pathway to protein secretion in Bacillus subtilis. J Biol Chem 2002, 277:44068-44078.

28. Bowler MW, Montgomery MG, Leslie AG, Walker JE: How azide inhibits ATP hydrolysis by the F-ATPases. Proc Natl Acad Sci USA 2006, 103:8646-8649.

29. Oliver DB, Cabelli RJ, Dolan KM, Jarosik GP: Azide-resistant mutants of Escherichia coli alter the SecA protein, an azide-sensitive component of the protein export machinery. Proc Natl Acad Sci USA 1990, 87:8227-8231.

30. Klein M, Hofmann B, Klose M, Freudl R: Isolation and characterization of a Bacillus subtilis secA mutant allele conferring resistance to sodium azide. FEMS Microbiol Lett 1994, 124:393-397.

31. Nakane A, Takamatsu H, Oguro A, Sadaie Y, Nakamura K, Yamane K: Acquisition of azide-resistance by elevated SecA ATPase activity confers azide-resistance upon cell growth and protein translocation in Bacillus subtilis. Microbiology 1995, 141:113-121.

32. Papanikou E, Karamanou S, Economou A: Bacterial protein secretion through the translocase nanomachine. Nat Rev Microbiol 2007, 5:839-851.

33. Slamti L, Lereclus D: A cell-cell signaling peptide activates the PIcR virulence regulon in bacteria of the Bacillus cereus group. EMBO J 2002, 21:4550-4559

34. Gilois N, Ramarao N, Bouillaut L, Perchat S, Aymerich S, Nielsen-Leroux C, Lereclus D, Gohar M: Growth-related variations in the Bacillus cereus secretome. Proteomics 2007, 7:1719-1728.

35. Lindbäck T, Granum PE: Detection and purification of Bacillus cereus enterotoxins. In Methods in Biotechnology, Volume 21: Food-Borne Pathogens: Methods and Protocols. Volume 21. 1 edition. Edited by: Adley CC. Totowa, NJ: Humana Press Inc; 2006:15-26.

36. Jongbloed JD, Grieger U, Antelmann H, Hecker M, Nijland R, Bron S, van Dijl JM: Two minimal Tat translocases in Bacillus. Mol Microbiol 2004, 54:1319-1325.

37. Kovács AT, Smits WK, Mironczuk AM, Kuipers OP: Ubiquitous late competence genes in Bacillus species indicate the presence of functional DNA uptake machineries. Environ Microbiol 2009, 11:1911-1922.

38. Wang IN, Smith DL, Young R: Holins: the protein clocks of bacteriophage infections. Annu Rev Microbiol 2000, 54:799-825.

39. Pallen MJ: The ESAT-6/WXG100 superfamily - and a new Gram-positive secretion system? Trends Microbiol 2002, 10:209-212.

40. Garufi G, Butler E, Missiakas D: ESAT-6-like protein secretion in Bacillus anthracis. J Bacteriol 2008, 190:7004-7011.

41. Dietrich R, Fella C, Strich S, Märtlbauer E: Production and characterization of monoclonal antibodies against the hemolysin BL enterotoxin 
complex produced by Bacillus cereus. Appl Environ Microbiol 1999, 65:4470-4474.

42. Harshey RM, Toguchi A: Spinning tails: homologies among bacterial flagellar systems. Trends Microbiol 1996, 4:226-231.

43. Josenhans C, Suerbaum S: The role of motility as a virulence factor in bacteria. Int J Med Microbiol 2002, 291:605-614.

44. Heuner K, Steinert M: The flagellum of Legionella pneumophila and its link to the expression of the virulent phenotype. Int J Med Microbiol 2003, 293:133-143.

45. Granum PE, Brynestad S, O'Sullivan K, Nissen H: Enterotoxin from Bacillus cereus: production and biochemical characterization. Neth Milk Dairy J 1993, 47:63-70.

46. Granum PE: Bacillus cereus. In Food Microbiology: Fundamentals and Frontiers. 3 edition. Edited by: Doyle MP, Beuchat LR. Washington D.C.: ASM Press; 2007:445-455.

47. Zhang MY, Lövgren A, Low MG, Landén R: Characterization of an avirulent pleiotropic mutant of the insect pathogen Bacillus thuringiensis: reduced expression of flagellin and phospholipases. Infect Immun 1993, 61:4947-4954

48. Gohar M, Økstad OA, Gilois N, Sanchis V, Kolstø AB, Lereclus D: Twodimensional electrophoresis analysis of the extracellular proteome of Bacillus cereus reveals the importance of the PIcR regulon. Proteomics 2002, 2:784-791.

49. Salvetti S, Faegri K, Ghelardi E, Kolstø AB, Senesi S: Global gene expression profile and phenotypic analysis of Bacillus cereus during active swarming migration. In PhD Thesis: Adaptive responses in Bacillus cereus group bacteriamicroarray comparisons and follow-up studies. Edited by: Fægri K. Faculty of Mathematics and Natural Sciences, University of Oslo; 2010.

50. Henrichsen J: Bacterial surface translocation: a survey and a classification. Bacteriol Rev 1972, 36:478-503.

51. Brillard J, Susanna K, Michaud C, Dargaignaratz C, Gohar M, NielsenLeroux C, Ramarao N, Kolstø AB, Nguyen-The C, Lereclus D, et al: The YvfTU two-component system is involved in plcR expression in Bacillus cereus. BMC Microbiol 2008, 8:183.

52. Ramarao N, Lereclus D: Adhesion and cytotoxicity of Bacillus cereus and Bacillus thuringiensis to epithelial cells are FlhA and PlcR dependent, respectively. Microbes Infect 2006, 8:1483-1491.

53. Bange G, Kümmerer N, Engel C, Bozkurt G, Wild K, Sinning I: FlhA provides the adaptor for coordinated delivery of late flagella building blocks to the type III secretion system. Proc Natl Acad Sci USA 2010, 107:11295-11300.

54. Gründling A, Burrack LS, Bouwer HG, Higgins DE: Listeria monocytogenes regulates flagellar motility gene expression through MogR, a transcriptional repressor required for virulence. Proc Natl Acad Sci USA 2004, 101:12318-12323.

55. Shen A, Higgins DE: The MogR transcriptional repressor regulates nonhierarchal expression of flagellar motility genes and virulence in Listeria monocytogenes. PLoS Pathog 2006, 2:e30.

56. Shen A, Higgins DE, Panne D: Recognition of AT-rich DNA binding sites by the MogR repressor. Structure 2009, 17:769-777.

57. Ehling-Schulz M, Svensson B, Guinebretière MH, Lindbäck T, Andersson M, Schulz A, Fricker M, Christiansson A, Granum PE, Märtlbauer E, et al: Emetic toxin formation of Bacillus cereus is restricted to a single evolutionary lineage of closely related strains. Microbiology 2005, 151:183-197.

58. Gominet M, Slamti L, Gilois N, Rose M, Lereclus D: Oligopeptide permease is required for expression of the Bacillus thuringiensis plcR regulon and for virulence. Mol Microbiol 2001, 40:963-975.

59. Lereclus D, Arantes O, Chaufaux J, Lecadet M: Transformation and expression of a cloned delta-endotoxin gene in Bacillus thuringiensis. FEMS Microbiol Lett 1989, 51:211-217.

60. Arantes O, Lereclus D: Construction of cloning vectors for Bacillus thuringiensis. Gene 1991, 108:115-119.

61. Heinrichs JH, Beecher DJ, MacMillan JD, Zilinskas BA: Molecular cloning and characterization of the $h b l A$ gene encoding the $B$ component of hemolysin BL from Bacillus cereus. J Bacteriol 1993, 175:6760-6766.

62. Masson L, Préfontaine G, Brousseau R: Transformation of Bacillus thuringiensis vegetative cells by electroporation. FEMS Microbiol Lett 1989, 51:273-277.

63. Guérout-Fleury AM, Shazand K, Frandsen N, Stragier P: Antibiotic-resistance cassettes for Bacillus subtilis. Gene 1995, 167:335-336.
64. Arnaud $M$, Chastanet A, Débarbouillé $M$ : New vector for efficient allelic replacement in naturally nontransformable, low-GC-content, grampositive bacteria. Appl Environ Microbiol 2004, 70:6887-6891.

65. Glatz BA, Goepfert JM: Defined conditions for synthesis of Bacillus cereus enterotoxin by fermenter-grown cultures. Appl Environ Microbiol 1976, 32:400-404.

66. Harlow E, Lane D: Antibodies: A laboratory Manual Cold Spring Harbor, NY: Cold Spring Harbor Laboratory; 1988.

67. Wehrle E, Moravek M, Dietrich R, Burk C, Didier A, Märtlbauer E: Comparison of multiplex PCR, enzyme immunoassay and cell culture methods for the detection of enterotoxinogenic Bacillus cereus. J Microbiol Methods 2009, 78:265-270.

68. Dietrich R, Moravek M, Burk C, Granum PE, Märtlbauer E: Production and characterization of antibodies against each of the three subunits of the Bacillus cereus nonhemolytic enterotoxin complex. Appl Environ Microbiol 2005, 71:8214-8220.

doi:10.1186/1471-2180-10-304

Cite this article as: Fagerlund et al: Bacillus cereus cytotoxins $\mathrm{Hbl}$, Nhe and CytK are secreted via the Sec translocation pathway. BMC Microbiology 2010 10:304.

\section{Submit your next manuscript to BioMed Central and take full advantage of:}

- Convenient online submission

- Thorough peer review

- No space constraints or color figure charges

- Immediate publication on acceptance

- Inclusion in PubMed, CAS, Scopus and Google Scholar

- Research which is freely available for redistribution

Submit your manuscript at www.biomedcentral.com/submit
C Biomed Central 